\title{
Brexit, the UK and Europe: Why, how and what next?
}

\author{
Stuart A. Brown ${ }^{\mathrm{a}}$
}

${ }^{a}$ LSE European Institute, London School of Economics, London, United Kingdom

Stuart A. Brown, LSE European Institute, London School of Economics, Houghton Street, London, WC2A 2AE, United Kingdom. E-mail: S.a.brown@1se.ac.uk / Twitter: @ StuartABrown01 


\title{
Brexit, the UK and Europe: Why, how and what next?
}

\begin{abstract}
Far from resolving the issue of the UK's relationship with the European Union, the Brexit referendum has opened up a series of complex questions that cut across academic disciplines. How will the vote affect British politics? Will Brexit damage the prosperity of the UK economy? What of the impact on wider European society and the trajectory of the integration process? This contribution reviews four recent publications that have sought to study the topic from distinct disciplinary approaches, integrating political, economic, sociological and legal perspectives.
\end{abstract}

Keywords Brexit; law; political economy; sociology; UK

Brexit: Why Britain Voted to Leave the European Union, by Harold D. Clarke, Matthew Goodwin, and Paul Whiteley, Cambridge: Cambridge University Press, 2017, 272 pp., £49.99 (hardback), ISBN 9781107150720

The Political Economy of Brexit, edited by David Bailey and Les Budd, Newcastle: Agenda Publishing, 2017, 192 pp., £60 (hardback), ISBN 9781911116639

Brexit: Sociological Responses, edited by William Outhwaite, London: Anthem Press, 2017, 224 pp., $£ 70$ (hardback), ISBN 9781783086443

The Law \& Politics of Brexit, edited by Federico Fabbrini, Oxford: Oxford University Press, 2017, 336 pp., £75 (hardback), ISBN 9780198811763

\section{Introduction}

The impact of Brexit on British politics has been both immediate and lasting, with David Cameron offering his resignation as prime minister the day after the vote, and his successor, Theresa May, finding her period in office come to be dominated by the issue of how to lead the country out of the EU. The economic impact remains difficult to ascertain, but few economists argue with the principle that Brexit, for good or bad, could have dramatic consequences for the UK economy in the coming years (Sampson 2017). Indeed, it is not an exaggeration to suggest that almost every aspect of British society, from the country's legal system, to citizens' feelings of identity and belonging, may ultimately be touched by the topic (Ashcroft and Bevir 2016). Moreover, these effects could yet have an expression across Europe, either by inspiring similar challenges to the participation of other member states in the EU, or by bringing the rest of the EU closer together in response (Taggart and Szczerbiak 2018).

The referendum was also a significant moment for academia. The most obvious consequence of the result has been to throw existing understandings of European integration into flux, generating countless research topics and new avenues for study in the process. But 
the campaign itself posed a unique challenge for the credibility of academics. Faced with the pressures of engaging with a highly polarised political debate, scholars had to balance the need to maintain neutrality with the temptation to satisfy demands for unequivocal answers to key campaign questions (Brown 2018). Accusations of academic bias became commonplace in the latter stages, with the former Secretary of State for Education and Secretary of State for Justice, Michael Gove, memorably responding to the broad perception that academics were in favour of remaining in the EU by stating that 'people in this country have had enough of experts' (quoted in Menon and Portes 2016).

Given its varied effects, there is some merit in approaching Brexit from an interdisciplinary perspective. In that spirit, this article reviews four books which have sought to capture the issue from distinct disciplinary approaches. All four contributions add some academic rigour to the question of why Britain voted to leave the European Union, while shedding light on what the vote is likely to mean for the British economy, the UK's legal system and wider European society. Though the four books amount to only a small snapshot of the work that has been done on Brexit since the referendum, they also provide tangible examples of the valuable role that academia can play in furthering our understanding of the process - a point which merits underlining in light of the rhetoric that put academics in the firing line during the campaign.

\section{Interpreting the vote to leave}

Although the notion that the polling badly misread the public's views has likely been overstated (see Clarke, Goodwin and Whitely 2016), there was nevertheless a widely held belief among observers that the vote would ultimately tip towards Remain. The most pressing question in the aftermath of the referendum was therefore why this belief had proven unfounded and what the key drivers of the vote had been.

Among the most convincing answers to have emerged are that Brexit reflected a divide between the 'winners' and 'losers' of globalisation (Hobolt 2016), a response to rising immigration (Goodwin and Milazzo 2017), and a collapse of trust in mainstream politicians (Marsh 2018). The key departure of Brexit: Why Britain Voted to Leave the European Union from many of these analyses lies in its focus on the long-term change in attitudes toward the EU during the years leading up to the vote. The argument is that while much of our attention has focused on short-term campaigning effects in influencing the outcome, several factors that produced the result were already in play over a decade earlier. The rise of UKIP, the 2014 European Parliament elections, and the 2015 UK general election all set the stage for the 2016 referendum, with the attitudes that underpinned the Leave vote becoming embedded in the electorate over a period of years, driven by dissatisfaction with the government's handling of core policy areas such as immigration, the economy, and healthcare.

This long-term focus is given some empirical weight through the use of extensive survey data stretching back to 2004. While the premise of situating Brexit in the context of a decades-long shift in attitudes is by no means entirely novel (see for instance Glencross 2016; Tomlinson and Dorling 2016), the argument is well made. The empirical case is exceptionally strong on the growth of UKIP, in particular, and taken together, the book amounts to one of the most detailed and convincing accounts available of the public sentiments that are now shaping British politics. 
If there is a flaw in this approach, it's that the analysis might have delved a little further into the past. The UK's position within the EU, which has evolved over decades, is an important factor for explaining the political context that shaped the debate: we could cite the ratification of the Maastricht treaty, the UK's decision to stay out of the single currency, and the growth of Euroscepticism in the British press in the 1990s as a starting point. The roots of Brexit are so multi-faceted that it would be impossible to do justice to all of them in a single volume, but for a book that adopts the long-term as its key approach, it may have benefited from a more thorough treatment of factors predating 2004.

This is made all the more pertinent given the choice to dedicate the final chapters to a discussion of the future for the UK beyond Brexit. Several of the points raised in this section break with the current academic consensus: notably the conclusion that EU membership has done little for UK economic growth, that losing access to the single market would have only a marginal impact on the prosperity of the UK economy, and the claim that the failure of Brussels to get auditors to 'sign off' on the EU budget demonstrates how weak the EU is in curbing corruption. There is nothing greatly troubling about the decision to challenge prevailing views on these topics, but the discussion nevertheless seems out of place in a book that has the aim of explaining why the public backed Brexit. The net result is that a study which shows an exceptional ability to illuminate our understanding of the past ends on a slightly polarising note about the future.

\section{Brexit and the economy}

The economic debate over Brexit was one of the key battlegrounds in the referendum campaign, but also one of the most problematic. Attempts to capture in a soundbite the economic costs and benefits of leaving the European Union resulted in overly simplistic, and at times outright misleading figures being promoted by both sides (Musolff 2017). Predicting the effect Brexit will have on the British economy is an undeniably complex undertaking, and many important factors were scarcely considered by campaigners and commentators prior to the vote.

The approach of The Political Economy of Brexit is therefore admirable for its commitment to uncovering these details. Much of the book is overtly technical in its focus: rather than seeking to make grand statements on whether Brexit is justified, each chapter is dedicated to pragmatic assessments of how it may impact on a specific sector or policy area. A good example is the chapter by John Bachtler on the role of Brexit in future regional development policy in the UK, which provides some valuable substance to a debate that has remained largely superficial in the political arena. It also underlines a message that appears frequently throughout the book: while Brexit can be viewed as both a problem and an opportunity in relation to many of the economic issues - regional inequalities among them that currently exist in Britain, it will be the commitment of the UK government, not Brexit itself, that will determine whether these issues can be resolved.

Other chapters touch on more heated political issues. Jim Gallagher's contribution on Brexit's consequences for Scotland argues forcefully that Scotland benefits economically from both its fiscal union with the UK and its membership of the European Union. With this stated, an undeniable lesson from the EU referendum is that the economy only matters to a point in polarised electoral campaigns (Kaufmann 2016). Just as the British public voted to leave the European Union despite the warnings of economists, it is entirely conceivable that 
Scottish voters could one day choose to back independence against a similar economic consensus.

The book is at its strongest when the nuances of an individual sector are used to cast light on the broader debate. Perhaps the best example of this is David Bailey and Lisa De Propris' discussion of the - at first glance, rather dry - subject of the UK's automotive industry. Their detailed illustration of the production process that goes into manufacturing a vehicle is a masterclass in demonstrating the role of cross-border value chains in modern trade, as well as the flaws of focusing exclusively on bilateral trade relations. It's precisely this kind of detail which was absent from discussions concerning trade during the referendum campaign, where attention was focused on tariffs and access to the single market, rather than the need to reduce non-tariff barriers and ensure these value chains remain frictionless.

\section{Sociological responses}

Brexit: Sociological Responses offers the most diverse collection of articles out of the four books considered here. Though billed as a sociological approach, several authors draw as much on political science as they do on sociology. Each contribution could easily be read independently as a short reaction piece written in the aftermath of the vote, but the collection is held together, as William Outhwaite notes in the preface, by a desire to place short-term political fluctuations in a broader social and historical context.

A highlight is Martin Westlake's contribution, which provides a clear assessment not only of how attitudes toward European integration have developed in the UK, but also of the role of referendums in British politics. To underline his case, he quotes Clement Attlee, responding to a proposal by Winston Churchill, as saying that he could not agree to the 'introduction into our national life of a device so alien to all our traditions as the referendum which has only too often been the instrument of Nazism and Fascism' (quoted in Bogdanor 1981, 35). Yet by the 2000s, the push for a referendum on Europe was becoming difficult to resist. The chapter expertly tracks how this dramatic shift in attitudes was facilitated by shortterm political calculations and commitments made by the country's three main parties, many of which appeared politically astute at the time, but which ultimately proved disastrous for the European cause in the long-term.

This historical account of how Brexit occurred is paired with an attempt by several authors to situate the vote within broader sociological and political trends that extend across Europe. These chapters go to the heart of how the Brexit vote should be characterised. Was the referendum really a revolt by the losers of globalisation? Was it an expression of disdain for London-centric cosmopolitanism? Or, as Gurminder K Bhambra examines, are some campaigners right to regard the outcome as a reflection of British attitudes toward race? These questions are fundamental because the decision made by the electorate is so heavily open to interpretation. Theresa May's government spent much of the period after the referendum attempting to settle on the type of Brexit that Leave voters expressed a desire for when casting their ballots. There is nothing new in politicians attempting to spin the result of an electoral contest to suit their own policy preferences, but in the case of Brexit, the consensus on this question dictates where the country moves next.

Bhambra's article is particularly thought-provoking in seeking to understand Brexit through the prism of Britain's imperial past: a topic that is frequently mishandled by political 
commentators, but which is admirably done justice here, whether one agrees with the premise or not. This also has the advantage of drawing an explanation from the unique circumstances present in the UK, something which Craig Calhoun achieves in a different fashion by focusing on the regional differences present within the country. While it is tempting to put Brexit in a European context, any attempt to do so must deal with the difficult question of why it is only in the UK that these broader forces have so far resulted in a vote to leave.

Another problem such arguments have to contend with is that there is a natural tendency to gravitate toward long-term explanations for political phenomena which may have been determined by short-term circumstances. Whereas Brexit: Why Britain Voted to Leave the European Union grounds its long-term perspective in a wealth of survey data and seeks to explain how attitudes adopted over a period of years interacted with the cut and thrust of the referendum campaign, there is a danger that if one applied some of the ideas in Brexit: Sociological Responses too forcefully then Brexit would start to appear something of an inevitable consequence produced by processes that lie beyond the control of political actors. These problems in no way undermine the many insights offered by the book's contributors, but it is apparent that only by combining these insights with other approaches are we likely to arrive at a full explanation.

\section{The legal dimension}

Finally, Brexit has obvious legal implications for both the UK and Europe. Yet despite a great deal of the referendum campaign focusing on issues such as the jurisdiction of the European Court of Justice, or which set of lawmakers are given control over a particular policy area, these factors were almost always approached from the politically charged perspective of 'sovereignty' and national 'control'. The Law \& Politics of Brexit seeks to present a more nuanced take on the topic, integrating the perspectives of lawyers, political scientists, and economists.

On the legal side, Paul Craig's chapter on the Article 50 process fleshes out the mechanics of the UK leaving the EU, something which is no easy task given the relatively sparse details contained in the treaty framework. Although events have somewhat overtaken this analysis, his conclusion that there would be great difficulties in securing both a withdrawal agreement and a comprehensive trade agreement within the two-year negotiating period has undoubtedly been confirmed since the chapter was written. This is paired with Giorgio Sacerdoti's examination of potential post-Brexit trade regimes, which provides some useful clarity on the topic of how trade agreements, the customs union, the single market, WTO rules and bespoke arrangements might come together in the negotiations.

However, potentially the most important contribution to the book is Uwe Puetter's assessment of the effect Brexit will have on the EU's institutional balance. Puetter has written at length elsewhere on his theory of 'deliberative intergovernmentalism', which is built on the observation that the European Council has acquired a central role in EU decision-making, with high-level attempts to reach consensus among Europe's political leaders becoming the main impetus for the integration process (Puetter 2014). Using this theory as a starting point, he provides a number of insights into what Brexit will mean for EU institutional dynamics. He notes that while the Commission appeared to be empowered by Brexit through the decision to assign it the task of leading the Brexit negotiations, the responsibility for giving political guidance on the EU's position, the capacity to compromise, and the decision to 
reject proposals remains tied to the member states. Alternatively, the notion that the loss of the UK may free other EU states to pursue closer integration must be understood, in Puetter's reading, from the present dynamics of EU decision-making, where states exhibit a paradoxical approach to integration: namely by seeking closer integration on principle, but resisting supranational empowerment at the European level.

Whether Puetter is proven correct in his assessment will be difficult to ascertain in the short-term. If Brexit has a profound effect on the trajectory of the integration process, it may well be one that is far less immediate than its impact on British politics or the other areas examined above. Yet it is equally possible that future studies of the integration process, written decades after the four covered here, will regard Brexit as little more than a side-note. Perhaps, once the shock of the first departure of a member state has dissipated, the EU will carry on much the same as it did before, just as it did when other states, such as Norway and Switzerland, chose to opt out of EU membership, albeit in radically different circumstances. The future is unlikely to be so simple for the UK itself, and one would imagine the topics considered in this review will continue to be revisited and reassessed by British academics for the foreseeable future.

\section{References}

Ashcroft, R., and Bevir, M. 2016. "Pluralism, National Identity and Citizenship: Britain After Brexit." The Political Quarterly 87 (3): 355-359.

Bogdanor, V. 1981. The People and the Party System: The Referendum and Electoral Reform in British Politics. CUP Archive.

Brown, S. A. 2018. "Britain's EU Referendum: How did Political Science Rise to the Challenge? An Assessment of Online Contributions During the Campaign." European Political Science: 1-15. doi:10.1057/s41304-018-0174-7.

Clarke, H. D., Goodwin, M., and Whiteley, P. 2016. "Leave Was Always in the Lead: Why the Polls got the Referendum Result Wrong." LSE European Politics and Policy (EUROPP) Blog.

Glencross, A. 2016. Why the UK Voted for Brexit: David Cameron's Great Miscalculation. London: Palgrave Macmillan UK.

Goodwin, M., and Milazzo, C. 2017. "Taking Back Control? Investigating the Role of Immigration in the 2016 Vote for Brexit." The British Journal of Politics and International Relations 19(3): 450-464.

Hobolt, S. B. 2016. “The Brexit Vote: A Divided Nation, a Divided Continent.” Journal of European Public Policy 23 (9): 1259-1277.

Kaufmann, E. 2016. "It's NOT the Economy, Stupid: Brexit as a Story of Personal Values. British Politics and Policy at LSE.

Marsh, D. 2018. "Brexit and the politics of truth.” British Politics 13 (1): 79-89. 
Menon, A., and Portes, J. 2016. "You're Wrong Michael Gove - Experts are Trusted Far More than You." The Guardian, June 9.

Musolff, A. 2017. "Truths, Lies and Figurative Scenarios." Journal of language and politics 16 (5): 641-657.

Puetter, U. 2014. The European Council and the Council: New Intergovernmentalism and Institutional Change. Oxford: Oxford University Press.

Sampson, T. 2017. "Brexit: The Economics of International Disintegration." Journal of Economic Perspectives 31 (4): 163-84.

Taggart, P., and Szczerbiak, A. 2018. "Putting Brexit into Perspective: The Effect of the Eurozone and Migration Crises and Brexit on Euroscepticism in European States." Journal of European Public Policy 25 (8) 1194-1214.

Tomlinson, S., and Dorling, D. 2016. "Brexit Has its Roots in the British Empire - So How Do We Explain it to the Young?.” New Statesman, May 9. 